\title{
The Impact of ESPZ on Students of Physical Education and Sports, University of Prishtina
}

\author{
Osman Osmani ${ }^{1 *}$ and Fikret Pajaziti ${ }^{2}$ \\ ${ }^{1}$ University of Prishtina "Hasan Prishtina”, Kosovo \\ 2"Jonuz Zejnullahu" high school \& Project Coordinator at Kosovo Pedagogical Institute, Kosovo
}

ISSN: 2577-1914

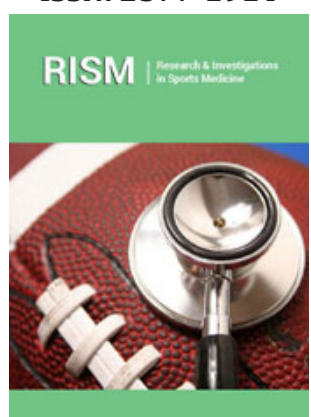

*Corresponding author: Osman Osmani, University of Prishtina "Hasan Prishtina", Kosovo

Submission: 温 March 09, 2020

Published: 眥August 13, 2020

Volume 6 - Issue 5

How to cite this article: Osman Osmani Fikret Pajaziti. The Impact of ESPZ on Students of Physical Education and Sports, University of Prishtina. Res Inves Sports Med, 6(5): RISM.000648. 2020. DOI: 10.31031/RISM.2020.06.000648

Copyright@ Osman Osmani, This article is distributed under the terms of the Creative Commons Attribution 4.0 International License, which permits unrestricted use and redistribution provided that the original author and source are credited.

\begin{abstract}
This paper investigated the current situation in regard to BA and MA English language courses taught at the Faculty of Physical Education and Sports (PES) at the University of Prishtina "Hasan Prishtina." The empirical research aimed to collect qualitative data by interviewing ten MA students of the same faculty. The findings revealed that it was their BA syllabus that contributed to their poor grasp of sports vocabulary in the context of the English language given that they were subjected to General English (GE) only. Unfortunately, their first contact with English for sports was in their first year of MA studies. Although the ESP course was only one semester, it had a positive impact on students' advancement. Moreover, students deemed ESP as a great way of building up their personality as sportsmen, given that it facilitated their way of approaching sports science with greater enthusiasm and effort.
\end{abstract}

Keywords: ESP; University students; Syllabus, General English; Bachelor; Master

\section{Introduction}

\section{Aims and objectives}

The aim of this research was to examine the impact of ESP course on second-year master's students at the PES faculty, University of Prishtina "Hasan Prishtina." One of our objectives was to find out their perceptions of ESP. Was it beneficial? Did it satisfy students' expectations and needs? These were the questions we wanted to provide with answers. We examined bachelor's and master's English syllabi at the PES faculty of "Hasan Prishtina". We sought to provide crucial results for both English professors and the faculty at large. Our findings will serve as a useful means of contributing to a vital and necessary change to improve students' education.

\section{Research problem}

If referring to this faculty program, first-year master's students are obliged to attend an English course for one term. In addition, they took an English course in the first year of their bachelor studies too, which, surprisingly, was solely focused on General English. While in contact with these students, we could see that their English vocabulary in terms of sports was almost non-existent. Many admitted that this affected negatively their experience at various international competitions. Even those who had the courage to take part in various competitions often avoided the media, because they were afraid of being asked in English. This dissatisfaction affected their success. Can we call it a success if one is not able to relate his/her value in front of an audience? It was definitely the lack of ESP that deprived them of promoting their values. What may fairly be considered a great shortcoming is clearly becoming an insurmountable barrier to our students. How can we overcome this huge barrier? That is the question we want to answer.

\section{Research hypotheses}

Our study is based on the following research hypotheses:

1. Failure to provide an ESP course in BA studies contributed to students' nonacquisition of English for sports.

2. The ESP course, though only one term, had a positive impact on MA students' sports vocabulary acquisition. 


\section{Research questions}

The following questions served as a map to design our research:

1. What is the impact of ESP on the advancement of PES MA students at Hasan Prishtina?

2. What are students' perceptions of ESP?

3. What are the consequences of not offering ESP courses for PES BA students?

\section{Significance of the research}

The significance of this research is multidimensional. Initially, the faculty management will have the chance to see students' perceptions, the advantages of ESP course for master's studies, and the possible disadvantages of its inclusion in the BA syllabus. Hopefully, they will consequently design new policies and intervene in the English syllabi, for which the respective professors are solely responsible at present. The findings of the study can also serve as a guide for future syllabi pertinent to PES English professors at Hasan Prishtina and other professors at private universities in general.

\section{Literature Review}

\section{The importance of the English language for students}

No matter where one goes, she or he cannot escape from hearing English words. English is used around the world and is rapidly spreading in the Balkans, too. Without English, nations could not be linked to each other. Its importance is reflected by the fact that even first-grade students in Kosovo are now being taught English. English is compulsory in both public and private schools and universities. Globalization has reached every society. The key to penetrating to the modern world is to know English. English is vital in every sphere of life: marketing, fashion, technology, sports, etc. To some extent, English is an inseparable part of people's lives. Sportsmen fall into this category. Therefore, PES students who travel to participate in different sports competitions must be equipped with English, especially ESP (sports terminology). Today's students know the importance of English for their education, their career, and ultimately their future. In a world where students have the mobility to study in different countries by earning different

\section{Findings and Discussion}

\section{Analysis of BA English Syllabus for PES Students (Table 1)}

Table 1: English course syllabus for BA students. scholarships, they have turned to English as their primary language of communication.

\section{English for specific purposes (ESP)}

In the 1960s, English for Specific Purposes emerged as a vital section of Applied Linguistics. ESP usually refers to teaching specific language skills in order for learners to master that particular field for their future job. Robinson (1991) states that not all students learn English out of interest or to gain general knowledge; rather, they need to be equipped with specialized vocabulary for their professional employment or their studies. Therefore, we can conclude that ESP helps students develop their skills in their particular field and workplace.

\section{Methodology}

\section{Introduction}

First, we examined the PES webpage to download, analyze, and discuss BA and MA English syllabi. Then we jumped into the second phase with our interviews.

\section{Participants}

The study is based on qualitative data from ten second-year PES master's students at Hasan Prishtina. The randomly selected participants were male and female from 23 to 45 years of age. The participants were of the same ethnic background considering the fact that there were no international students in this class.

\section{Instruments}

We used English interviews to pose questions on the BA and MA English language course offerings to gather the data.

\section{Procedure}

Interviews took place in amphitheater number one at the public University of Prishtina "Hasan Prishtina" faculty of Physical Education and Sports from November 9th to 14th, 2017. After giving their consent, students were recorded by a mobile phone. For the sake of acquiring objective results, and in order to make them feel more comfortable, they were not required to give us any personal data. They were encouraged to carefully consider the questions before answering them. It took them no longer than 10 to 15 minutes each.

\begin{tabular}{|l|c|}
\hline \multicolumn{2}{|c|}{ Designated Learning Plan } \\
\hline Week & Course introduction \\
\hline $1^{\text {st }}$ week & Greetings. Introductions, the verb to be \\
\hline $2^{\text {nd }}$ week & Country names. Negative and interrogative forms. Writing a letter \\
\hline $3^{\text {rd }}$ week & Jobs. Present simple tense: negative and interrogative forms. Telling the time \\
\hline $4^{\text {th }}$ week & Family and society. Present simple. Social expressions. Seasons \\
\hline $5^{\text {th }}$ week & Home and furniture. The indefinite article a/an. Demonstratives, this/that \\
\hline $6^{\text {th }}$ week & Can/could. Was/were. Reading about three talents \\
\hline $7^{\text {th }}$ week & \\
\hline
\end{tabular}




\begin{tabular}{|c|c|}
\hline $8^{\text {th }}$ week & Past simple tense. Irregular verbs. Famous people \\
\hline $9^{\text {th }}$ week & Past simple tense 2. Simple past \\
\hline $10^{\text {th }}$ week & Food. Nouns. Much/many. Requests and offers (Would you...) \\
\hline $11^{\text {th }}$ week & Comparative adjectives. Have/have got. Reading about three musical cities \\
\hline $12^{\text {th }}$ week & Present continuous. Clothes \\
\hline $13^{\text {th }}$ week & Concluding remarks and final test \\
\hline
\end{tabular}

In examining the current PES English syllabus on its webpage, we find that it is solely based on General English (GE). The main focus is on grammar. Not a single session includes anything regarding sports. Considering the conditions of society and labor market demands, this faculty is supposed to prepare referees, coaches, sportsmen, and teachers with vocational skills by offering them English instruction for sports. The PES faculty should equip students with the skills needed to adapt to the demands of the world of sports. As in other European countries, students in our country would benefit from foreign language courses for specific purposes. The current PES syllabus is not designed for the faculty it serves. It is solely based on a traditional approach where the students are required to read out loud, translate, and learn grammar. In terms of its content, the current syllabus provides university students with very basic knowledge (e.g., the alphabet, articles, vowels, and consonants) of English, which does not align with their level and demands.

\section{Analysis of BA English Textbooks for PES Students (Table 2)}

Table 2: English course material for BA students.

\begin{tabular}{|c|c|c|}
\hline Title & Author & Publisher \\
\hline New Headway English, Third Edition Student's Book & Liz and John Soars & Oxford University Press \\
\hline $\begin{array}{c}\text { New Headway English, Third Edition Elementary } \\
\text { Workbook }\end{array}$ & Tim Falla, Liz Soars, and John Soars & Oxford University Press \\
\hline
\end{tabular}

BA students are still being taught based on the content offered from the third edition of the New Headway English course, which is elementary A1 (CEFR) level English. After genuine research, we found out that 9 th graders in lower-secondary education are taught from the very same book. After examining syllabi of uppersecondary schools, we learned that 10 th graders are taught with pre-intermediate books, 11thgraders with intermediate ones, and 12thgraderswith upper-intermediate. Not even a single paragraph

\section{Analysis of MA english syllabus for PES students (Table 3)}

Table 3: English course syllabus for MA students.

\begin{tabular}{|c|c|}
\hline \multicolumn{2}{|r|}{ Designated Learning Plan } \\
\hline Week & Lecture \\
\hline $1^{\text {st }}$ week & Introducing the subject content; methodology, assessment, and literature; Why is English so important? \\
\hline $2^{\text {nd }}$ week & It's my club: positions, pitch, jobs; greetings and introductions; personal information; Present Simple \\
\hline $3^{\text {rd }}$ week & Defender: set-pieces, goal position; talking about routine, play/do/go (to) sports; football match vocabulary \\
\hline $4^{\text {th }}$ week & Midfielder: writing emails \\
\hline $5^{\text {th }}$ week & Striker: shots and goals; great strikers; past simple and past continuous; word story; "thief" acting activity \\
\hline $6^{\text {th }}$ week & Goalkeeper: goal-keeping skills; computer games; round table discussion \\
\hline $7^{\text {th }}$ week & Test \\
\hline $8^{\text {th }}$ week & Scout: describing players, skills in each position; watching and discussing a short film \\
\hline $9^{\text {th }}$ week & The Olympic Games: Summer and Winter Olympics; Present Perfect Tense \\
\hline $10^{\text {th }}$ week & Manager: managers or coaches; imperatives; volleyball \\
\hline $11^{\text {th }}$ week & Let's talk about sports: extreme sports; \\
\hline $12^{\text {th }}$ week & Swimming, sailing, handball \\
\hline $13^{\text {th }}$ week & Projects and Presentations \\
\hline
\end{tabular}

of the elementary book's 14 chapters contains anything regarding sports. Besides, why are university students being taught with lower-secondary school books? Logically, they should be taught a higher level of English since their level is undoubtedly higher than it was in secondary school. The student (user) at an A1 level is described as a "Basic User" with basic language skills. The table below better expresses what is expected from those who attend A1 English courses. 
As seen above, the MA syllabus is designed to offer students language learning based on two crucial components: ESP and GE. Its topics include communication activities in the domain of sports and what students need to know about a career in sports. It is not based on a traditional approach; rather, the learning activities include audio and films, different games, round table discussions, and acting - which of course arouse a sense of motivation in students who will find the lectures very attractive, interesting, and useful under any circumstances. Everything they learn in the class, they can reproduce using actions; they are putting their thoughts into words. The MA syllabus is also designed to strengthen students' general knowledge by focusing on the four language skills (i.e., reading, writing, speaking, or listening) even though the speaking skill is emphasized the most.

After attending MA English sessions, students are expected to enrich their own vocabulary in terms of English for sports. Their writing skill will be developed appropriately by writing formal and informal emails and seminar papers. This is undoubtedly crucial to master's students because they are expected to present in national and international conferences, as well as different symposiums. The students will also be able to use English as a source of information in their professional fields.

\section{Analysis of MA english textbooks for PES students}

The table below shows the MA English textbooks for PES students at Hasan Prishtina (Table 4). It is almost impossible to work with a single textbook without feeling the need for additional material. Sometimes materials are difficult to acquire, and we need to find different sources. This includes the process for the selection, adaptation, and production of the materials. In order to prepare more reliable materials, we must be aware of what is being studied, so we have to ask students and professors about the existing content being taught to students. The cooperation of ESP professors with subject course professors is very important.

Table 4: English course material for MA students.

\begin{tabular}{|c|c|c|}
\hline \multicolumn{2}{|c|}{ Literature } \\
\hline Basic literature & 1. $\quad$ Redmond, A, Warren, S (2012) English for Football. Oxford University Press, United Kingdom. \\
\hline Additional literature & $3 . \quad$ Pre-Intermediate Student's Book, Oxford University Press, (Fourth edition), United Kingdom. \\
\hline & & 1. Kay, S, Jones, V. New Inside Out Sport. Macmillan Education.
\end{tabular}

As is evident from the MA Syllabus, students are offered lectures based on three books, two of which focus mainly on ESP and one in GE. Eight chapters of English for Football were mainly on football. On the other hand, New Inside Out (NIO) is a compilation of different sports (e.g., Olympics, boxing, extreme sports, etc.). It also includes biographies of some of the most important sports figures in the world like Muhammad Ali and Lionel Messi. This book combines levels from the pre-to upper intermediate. Lessons based on such content would obviously equip students with sports vocabulary and satisfy their expectations.

\section{ESP syllabus design for PES faculty}

It requires great effort and analysis to design an ESP syllabus on sports. However, this is not impossible. The teacher should be very careful and conscious about it. Although challenging, it gives teachers a great feeling to know they are meeting their students' needs (which should be the aim of every teacher). When teachers work to materialize their students' needs, they are shaping their students' future destinies.

The English teacher should focus the content of the course and students' needs, and provide flexible materials relevant to their sports field requirements. If no adequate book on sports is available, s/he should try to extract different texts from relevant internet resources and compile the same content while considering the four language skills (GE should not be neglected since students need it on a daily basis).

Producing and compiling such materials may be challenging and tiring for those who have never attended training on syllabus design. However, Hutchinson and Waters provide some principles to designing teaching material:

1. The material should be carefully selected because it is considered a catalyst for students' learning. It is not the teaching that matters, it is the means of encouragement; therefore, the material should be:

a. Interesting;

b. Attractive which stimulates the students' thinking capacity, and

c. be built upon the content which is suitable for both teachers and students;

2. The material should be coherent and explicit; it should serve to maximize students' learning ability, and

3. The material should be composed of appropriate language [1].

After completing the course syllabi and providing students with relevant ESP material for their particular field of study, the role of the teacher becomes that of "a monitor, classroom manager, instructor, and consultant" [2]. 


\section{Qualitative Data}

After gathering the data, we transcribed the interviews and discussed them thoroughly.

\section{Students' perspectives on ESP course}

The importance of English for PES students was unanimously asserted by all interviewees for a variety of reasons. Firstly, Albanian literature in terms of sports lacks. As a consequence of its lack, they have to address to material in other languages, mainly in English. However, if they lack English for sports, then it is considered a major obstacle to their success.

95\% of the interviewees hold the opinion that it is ESP that really meets their needs, although GE had its own benefits too. "Considering the fact that physical education is a specific field, sports vocabulary is more beneficial than just learning grammar rules and so on," they reported. ESP is certainly very useful for these students' future careers as sportsmen, coaches, or sports pedagogues.

The current MA English syllabus helped students a lot. It enabled them to better communicate with their international peers and colleagues. They could find enough literature for scientific research and enhance their knowledge in their field of study. All the interviewees claimed that ESP is a necessity for PES students. This is a great motivator to encourage English teachers to adapt to their students' needs. English in PES should be adapted to subject courses. As a result, everything connected to sports would be less complicated and far easier to learn.

Despite the importance of GE, students have a higher opinion of ESP, although it only materialized in recent times. English sports vocabulary is the main artery for PES students to understand the subjects they study. Sportsmen travel a lot. Wherever they go to competitions, sports meetings, or conferences - they have to talk in English and are linked to other sportsmen through sports vocabulary. Since English has become a global language, sport itself has followed the same trend. Sportsmen are ambassadors of their countries; if they win medals, they are expected to give speeches or be interviewed about that particular sport in English. Thus, the lack of contextual language would embarrass them and give a poor impression of their nation in front of a huge audience. Students agree that ESP would shape and complete their personality as real professionals, and acts as a steppingstone to build up their career as both sportsmen and future teachers.

One of the questions asked students to share their individual experiences as sportsmen in any international competition where they encountered difficulties from being ill-equipped with English for sports. They responded differently (except for those who did not have the chance to travel abroad or be in contact with their English-speaking counterparts or opponents). However, all those who represented our nation in international competitions admit that they faced difficulties very often. Not a single one of them found it easy to communicate in English for sports.
One interviewee, who is very successful in his field, recounted that he has often been asked to bring his ideas and achievements to an international level, but his lack at English created a disconnection between his talent and his ability to promote his values in karate. "A sportsman who does not acquire English in general, and English for sports in particular is handicapped," were his words. The impact of the lack of ESP was obvious. Although, he was equipped with energy to penetrate the international world of sports, his dream vanished. He is now hopeless because he was forced to be an ordinary sportsman - isolated and unknown worldwide.

Another student who represented Kosovo in the 2003 Special Olympic Games in Ireland faced great difficulties with English for sports. This somehow made her feel inferior compared to other competitors. At that time, she used to work as a lecturer for the "Health and Recreation" course. While teaching, she said she heard many words in English for the first time, although she had learned the same ones in Albanian. She said, "When I consulted a dictionary, I knew I had learned them in my mother tongue, but never in English. I never had a chance to learn them since my learning was based mostly on grammar rules." Doubtless, the impact of the lack of an ESP course is indisputable.

One of the students, who is actually the head of students at the PES Department, said that he once found himself in a very difficult position while giving a speech to an international audience. "At the very opening of my speech, I was good, but meanwhile I had to talk about specific fields of sports, particularly in gymnastics. While speaking, all of the sudden I remained speechless. This happened due to the fact that I wasn't familiar with English for sports. I was really embarrassed at that moment," he said. When asked who was to blame for his bad performance in English, he responded that it was the syllabus and the faculty policies on English syllabi.

All the experiences they shared with us occurred during their undergraduate studies. At that time, no ESP course was offered to them, only GE. The consequences of the lack of an ESP course accompanied them throughout their lives. It was only in their MA studies when English sports were instilled in their vocabulary. But, one term only cannot perform miracles.

\section{Researchers' perspectives on ESP}

Almost every graduate has to adapt to the demands of the labor market by focusing on learning the language of his or her future profession. PES students increasingly feel the need to learn ESP. Therefore, the English language professors of this faculty must honor the great responsibility of this course and should be committed to adapting to the needs of their students. ESP must have an important place in the studies of our future sportsmen.

In order for a referee to be accredited by FIFA and the UEFA, s/ he has to know English. Suppose a referee whistles because one of the players tackled an opponent and committed a foul. The player would approach him to ask, "Why did you stop the match? It was not a foul." By not knowing English for sports, the referee may 
either say something wrong or give no response at all. However, if the media inquire about that controversial foul later on, he might need to sneakily avoid the question because he is not equipped to respond correctly.

In another situation, one might be a great coach in his own country but cannot get a job for an international club because of his poor English. He would have to train players of different nationalities. How could he advise, criticize, or rebuke his players if he does not know the language which unites every nation of the world? How could s/he give instructions to his/her players before and after the match? There is no way he could be employed internationally.

ESP can be highly focused on "developing scientific and technical communication" [3]. On the other hand, a GE course has more general objectives; it refers to English as "a good thing to be taught as part of a broad education"[4]. Therefore, the syllabus of ESP should provide students with phrases they can put to practice immediately. Since students need to use English in communication in real-life situations, knowing the language that is truly used is indispensable.

ESP involves creating a program with distinct communication needs. Communication can be performed not only through listening skills and spoken language, but also through writing skill. The ESP course enables these skills to be taught at the level of communication and not "in a segmental or syntactic level," as in the GE course. The ESP course should be focused on teaching micro-skills rather than learning about macro-skills, as in the GE course [5]. These micro-skills are specified based on an analysis of students' communication needs.

\section{Conclusion}

Our research was designed to answer the questions stated in the first chapter. It was mainly focused on examining the impact of ESP on MA students at the PES faculty, University of Prishtina, "Hasan Prishtina." It aimed at examining BA and MA syllabi in order to determine which one was more suitable and beneficial to students. The BA English course was composed of GE only. It was based on A1 level. Moreover, it was too basic and did not meet the students' needs. As a result, the students were not encouraged to study hard. On the other hand, the MA syllabus combined ESP and GE, though ESP dominated. Interviewees unanimously affirmed that it met their expectations and satisfied their needs. Being subjected to contextual language, PES students are expected to acquire English for sports more easily. This is due to the fact that they are already equipped with sports vocabulary in their native language. The lack of ESP courses at BA studies deprived students of success and positive opportunities in their sports careers $[6,7]$.

The impact of the ESP course on MA students was far greater than the GE one. Students do not deny the fact that both of the courses had their own positive qualities; however, the experiences they had with international sportsmen frequently embarrassed them due to their lack of sports vocabulary. It also stopped them from promoting themselves in international arenas. We, therefore, encourage PES professors to offer more ESP courses - its impact on students will surprise them.

\section{Limitations of the Study}

The study included qualitative data only and was conducted with a limited number of students (namely 10). The study was only carried out in the context of the faculty of Physical Education and Sports at the public University of Prishtina, "Hasan Prishtina" in Kosovo. Consequently, the small sample was not representative of PES faculties in private universities in the Republic of Kosovo too. If the study is to yield more generalizable and reliable findings, it needs to involve a greater number of students from both public and private universities.

\section{References}

1. Hutchison T, Waters A (1987) English for specific purposes: a learnercentered approach. Cambridge University Press, England, UK.

2. Benyelles R (2009) Teaching ESP at post-graduate level. University of Tlemcen, Algeria.

3. Widdowson HG (1979) Exploration in applied linguistics. Oxford, UK.

4. Bates M (1978) English for specific purposes. Longman, London, UK.

5. Falvey P (1979) Current trends in english for special purposes: a survey. IDELTI Journal 13.

6. Robinson P (1980) English for specific purposes. Pergamon, Oxford, UK.

7. Faculty of Physical Education and Sports, English Language syllabus, University of Pristina, Kosovo. 